\title{
Juta's Concise Dictionary of Accounting Terms with their Afri- kaans Equivalents
}

\author{
N. Stegmann, Departement Rekeningkunde, Randse Afrikaanse Universiteit, \\ Johannesburg, Republiek van Suid-Afrika
}

Opsomming: Die derde uitgawe van die woordeboek is in 1996 saamgestel in 'n tyd toe die standaardiseringsproses van terme in die middel van 'n internasionaliseringsproses was. Die meeste van die Standpunte oor Algemeen Aanvaarde Rekeningkundige Praktyk wat as riglyn vir die rekeningkunde dien, is hersien en in ooreenstemming met die Internasionale Rekeningkundige Standaardekomitee se voorskrifte gebring. Aangesien rekeningkundige terminologie bepaal word deur hierdie Standpunte oor Algemeen Aanvaarde Rekeningkundige Praktyk, is 'n groot aantal van die terme in die woordeboek verouderd. Omdat enige skrywer van ' $n$ rekenkundige handboek weerloos is teen sulke veranderinge, het die resensent probeer om terme te identifiseer wat sedertdien verander het of nie voorheen in die rekeningkunde gebruik is nie. Die woordeboek is ' $n$ nuttige werkboek vir enigeen wat geïnteresseerd is in die terminologie wat in die rekeningkunde gebruik word, maar sal veral bruikbaar wees vir studente wat op hoogte moet kom van die vaktaal van die rekeningkunde.

Sleutelwoorde: UNIEKE POSISIE, VERKLARINGS VAN ALGEMEEN AANVAARDE REKENKUNDIGE PRAKTYK (GAAP), GEKODIFISEERDE GAAP, INTERNASIONALISERINGSPROSES, VEROUDERDE TERME, ONVOLDOENDE OMSKRYWINGS, AANGEPASTE OMSKRYWINGS, NUWE TERMINOLOGIE

\begin{abstract}
Juta's Concise Dictionary of Accounting Terms with their Afrikaans Equivalents. The third edition of the dictionary was composed in 1996 at which time the standardization process of terms was in the middle of an internationalisation process. Most of the South African Statements of Generally Accepted Accounting Practice which serves as guideline for accounting were revised and brought into compliance with the International Accounting Standards Committee's regulations. As accounting terminology is determined by these Statements of Generally Accepted Accounting Practice, a large part of the terms in the dictionary is outdated. Because any author of an accounting text book is defenceless against such changes, the reviewer attempted to identify terms that have since been changed or not been used in accounting previously. The dictionary is a helpful tool for anybody interested in the terminology used in accounting, but will be especially useful for students who need to acquaint themselves with the technical language of accounting.
\end{abstract}

Keywords: UNIQUE POSITION, STATEMENTS OF GENERALLY ACCEPTED ACCOUNTING PRACTICE (GAAP), CODIFIED GAAP, INTERNATIONALISATION PROCESS, 
ANTIQUATED TERMS, INSUFFICIENT DESCRIPTIONS, MODIFIED DESCRIPTIONS, NEW TERMINOLOGY

\section{Inleidend}

\subsection{Unieke posisie van rekeningkunde}

Rekeningkunde beklee 'n unieke posisie in die ekonomiese en bestuurswetenskappe aangesien die vakgebied deur 'n standaardeliggaam gereguleer word. Hierdie liggaam staan as die Suid-Afrikaanse Instituut van Geoktrooieerde Rekenmeesters (SAIGR) bekend. Die SAIGR kodifiseer Algemeen Aanvaarde Rekeningkundige Praktyk (AARP) in Suid-Afrika deur middel van Standpunte oor Algemeen Aanvaarde Rekeningkundige Praktyk na goedkeuring deur die Rekeningkundige Praktykeraad. Die Rekeningkundige Praktykeraad bestaan uit 'n wye groep verteenwoordigers van alle belanghebbende institute en liggame wat belange by finansiële verslagdoening in Suid-Afrika het. Die terminologie wat in die Standpunte oor Algemeen Aanvaarde Rekeningkundige Praktyk gebruik word, is dus aanvaarbaar vir 'n wye reeks belanghebbendes. Die SAIGR is ook tans besig met 'n internasionaliseringsproses deur middel waarvan Suid-Afrikaanse Standpunte oor Algemeen Aanvaarde Rekeningkundige Praktyk in ooreenstemming met internasionale standaarde gebring word.

Dit behoort dus duidelik te wees dat terminologie in rekeningkunde tot 'n groot mate gereguleer word deur Standpunte oor Algemeen Aanvaarde Rekeningkundige Praktyk deurdat die meeste rekeningkundige terme in Standpunte oor Algemeen Aanvaarde Rekeningkundige Praktyk omskryf word.

\subsection{Gekodifiseerde AARP as uitgangspunt}

Die Juta's Concise Dictionary of Accounting Terms word hoofsaaklik deur studente en rekenmeesters gebruik. Daar word ook aanvaar dat gebruikers van finansiële state die woordeboek benut wanneer finansiële state bestudeer word. Indien die beperkende raamwerk van terminologie soos vasgestel in Standpunte oor Algemeen Aanvaarde Rekeningkundige Praktyk in ag geneem word, behoort dit duidelik te wees dat dit sinneloos is om van hierdie vasgestelde terminologie af te wyk, aangesien voorbereiders van finansiële state juis veronderstel is om binne die gegewe raamwerk te opereer.

\section{Verbeteringe}

Die woordeboek is volledig indien die datum van publikasie in ag geneem word, aangesien die woordeboek midde-in die omvattende internasionalisering van Standpunte geskryf is. Vanweë die snelontwikkelende aard van 
gekodifiseerde Algemeen Aanvaarde Rekeningkundige Praktyk, is die woordeboek noodwendig verouderd en het die werk met die huidige inhoud nie veel gebruiksnut nie. Hierdie situasie is heeltemal buite die outeurs se beheer en daarom is die kommentaar hoofsaaklik daarop gerig om terme wat sedert die publikasie van die woordeboek omskryf of gewysig is, te identifiseer.

\section{Formaat}

Die formaat van die woordeboek is baie gebruikersvriendelik. Die waarde van die werk word aansienlik verhoog deur die verskaffing van voorbeelde van waardasiemetodes vir voorraad, waardeverminderingsberekenings en finansiële state. Die voorbeelde van die finansiële state is egter verouderd, aangesien 'n nuwe standpunt 'n gewysigde formaat voorstel. Die verskaffing van Afrikaanse terme met hul Engelse ekwivalente is baie nuttig vir Afrikaanse studente en voorbereiders van finansiële state.

\section{Werkswyse}

Die woordeboek is noukeurig bestudeer en kommentaar word oor alle aspekte gelewer wat aandag verdien. Met inagneming van die raamwerk wat hierbo uiteengesit is, word verouderde terme uitgewys, veranderinge wat deur gewysigde Standpunte van Algemeen Aanvaarde Rekeningkundige Praktyk vereis word, aanbeveel en 'n lys verskaf van terme wat sedert publikasie algemeen aanvaarde rekeningkundige terme geword het en wat in die woordeboek bygevoeg behoort te word. Die woordeboek bevat slegs enkele foute wat ook geïdentifiseer word met aanbevelings ter regstelling.

\section{Foutiewe of ontoereikende beskrywings}

Die omskrywing van die volgende term word bevraagteken:

Account (for) Die gebruik van die term "explain" in die beskrywing "To explain, substantiate or record the effect of a transaction" is foutief. In die rekeningkunde beteken die term "account (for)" dat ' $n$ transaksie in die boek van eerste inskrywing aangeteken word.

Die omskrywing van die volgende term behoort eerder te lui:

Accounting Rekeningkunde. The process of identifying, measuring, recognising, presenting and disclosing economic information to facilitate informed judgements and decision making by users of the information. 
Die volgende vertalings van terme word bevraagteken:

Accrual (adjustments, basis of accounting) en Accrue Oplopingsaansuiwering, Oplopingsbeginsel en Oploop behoort vervang te word met Toevallingsaansuiwering, Toevallingsaansuiwering en Toeval (verwys RE 000.22).

Assessed loss Belastingsverlies behoort vervang te word met Aangeslane verlies. Die beskrywing behoort ook gewysig te word na "The excess of tax deductible expenses over taxable income as confirmed by SARS".

Cash on delivery Kontant by aflewering is die meer aanvaarde term. Dit word algemeen as $K B A$ afgekort.

Directors' report Direkteursverslag is verkieslik bo Direkteureverslag.

Excess of expenses over revenue Tekort. Nie Oorskot soos dit tans vertaal is nie.

Expenditure Besteding. Nie Uitgawes soos dit tans vertaal is nie.

Inflation accounting Inflasie-rekeningkunde. Hierdie tipe rekeningkunde verantwoord die effek van algemene prysverhogings en nie bloot die effek van stygende pryse nie. Die beskrywing "rising prices" behoort vervang te word met "general increases in prices".

Purchases journal Aankoopjoernaal. Nie Aankopejoernaal nie.

Purchases returns Aankoopterugsendings; aankoopretoere. Nie Aankopeterugsendings; aankoperetoere nie.

Purchases returns journal Aankoopterugsendingsjoernaal. Nie Aankopeterugsendingsjoernaal nie. Verder hoort Aankopejoernaal, die vertaling van Purchases journal, glad nie hier nie.

\section{Onvolledige omskrywing van terme}

Die volgende terme se omskrywings is na die skrywer se mening onvolledig:

Liquidate Likwideer. Daar behoort 'n verwysing te wees na Wind up.

Fair value Billike waarde. Die volgende omskrywing behoort bygevoeg te word: "The amount for which an asset could be exchanged or a liability settled between knowledgeable, willing parties in an arm's length transaction" (AC 123.10).

Reserve Reserwe. Daar behoort bygevoeg te word dat reserwes 'n onderdeel van ekwiteit is en dat dit ook ontstaan as gevolg van winste wat nie aangewend is nie.

Rights issue Regte-uitgifte. Daar moet vermeld word dat sodanige uitgifte plaasvind in 'n sekere verhouding tot bestaande aandelebesit. 


\section{Onvoldoende vertaling van terme in Afrikaans}

Die volgende Engelse terme kan aangevul word met alternatiewe vertalings:

Acceptor Aannemer. Dit word ook algemeen in die praktyk as akseptant vertaal.

Accounting date Rekeningkundige datum. Dit word meer algemeen as rekenpligtige datum vertaal.

Accounting period Rekeningkundige tydperk. Dit word tans as rekenpligtige tydperk vertaal (verwys RE 101.50).

Ageing Debiteureveroudering. Die term word meer algemeen met debiteureontleding vertaal.

Allocate Toewys. Die term word meer algemeen met toedeel vertaal.

Application and allotment account Aansoek- en toekenningsrekening. Dit kan ook vertaal word met aansoek- en toewysingsrekening.

Closing balance Sluitingsaldo. Dit word meer algemeen as eindsaldo vertaal. Die byvoeging van die sin "Stock is usually valued at the lower of cost and net realisable value" as deel van die verklaring van hierdie term word bevraagteken.

Credit By (1) moet Krediet vervang word met Krediteer. Die volgende moet bygevoeg word: Crediting Kreditering. The recording of a credit entry in the ledger account.

Current ratio Bedryfsverhouding. Dit word meer algemeen met die term bedryfskapitaalverhouding vertaal.

Debit Debiet moet vervang word met Debiteer. Die volgende moet bygevoeg word: Debiting Debitering. The recording of a debit entry in a ledger account.

Favourable balance Batige saldo. Voordelige saldo word ook algemeen gebruik.

Fixed overhead Vaste bokoste. Vaste drakoste is die verkieslike term ingevolge RE 108.

Flat rate of interest Uniforme tarief; rentekoers. Bytelkoers word die meeste in die praktyk gebruik.

Gearing Hefboomwerking. Die omskrywing is eerder dié van hefboomwerking as van hefboomfinansiering. (Verwys Leverage).

Participating preference shares Deelnemende voorkeuraandele. Winsdelende voorkeuraandele kan as alternatief bygevoeg word.

Pre-incorporation profits/losses Voorinkorporasiewinste/-verliese. Voorinlywingswinste/-verliese kan as alternatiewe bygevoeg word.

Profit-sharing ratio Winsverdelingsverhouding. Hiernaas kan winsdelingsverhouding bygevoeg word.

Subsidiary books By-boeke. Dié term word selde gebruik. Hulpboeke is meer gebruiklik.

Subsidiary ledger Memorandumgrootboek. Die term hulpgrootboek word meer algemeen gebruik. 
Work in progress Onvoltooide werk; werk-aan-die-gang. Die volgende kan ook bygevoeg word: werk-in-proses; werk-in-voortgang.

\section{Verouderde terme}

Die volgende terme is verouderd ingevolge Standpunte oor Algemeen Aanvaarde Rekeningkundige Praktyk en behoort nie meer algemeen gebruik te word nie:

Abnormal item Abnormale item.

Associated company Geassosieerde maatskappy. Die terme word vervang met Associate en Geassosieerde.

Book value Boekwaarde; drawaarde. In RE 123.10 word die terme Carrying amount Drabedrag gebruik.

Contingency Gebeurlikheid.

Contingent gain/loss Voorwaardelike wins/verlies.

Discontinued operation Beëindigde bedrywigheid. Die terme Discontinuing en Eindigende word tans in AC 117 en RE 117 gebruik.

Fixed asset Vaste bate. Die terme word vervang deur Non-current asset en Niebedryfsbate in AC 101 en RE 101.

Holding company Houermaatskappy. Hierdie terme is vervang met Parent company Moedermaatskappy, maar word nog baie in die praktyk gebruik en oorweging behoort geskenk te word aan die behoud van die ou terme in die woordeboek.

Net current assets Netto bedryfsbates. Ondernemings mag nie meer bates en laste teen mekaar verreken nie (RE 101.34). Dieselfde geld vir Net monetary assets Netto monetêre bates.

Net income Netto inkomste. Die term word nou vervang met Netto wins. (Verwys ook na Net income before/after tax).

Outside shareholders Buite-aandeelhouers. Hierdie terme is vervang met Minority interest Minderheidsbelang in RE 131 en AC 131, maar word nog baie in die praktyk gebruik en oorweging behoort geskenk te word aan die behoud van die ou terme in die woordeboek.

Permanent difference Permanente verskil/Blywende verskil. Hierdie terme word nie meer gebruik in die nuwe AC 102 en RE 102 nie.

Source and application of funds statement Staat van bron en aanwending van fondse. Dit is ' $\mathrm{n}$ staat wat nie meer voorberei word nie.

Stock Dit is in AC 108 algemeen met Inventories vervang.

Timing differences Tydsberekeningsverskille. Hierdie terme is vervang met die terme Temporary differences Tydelike verskille in AC 102 en RE 102. 
9. Wysigings vereis deur Standpunte oor Algemeen Aanvaarde Rekeningkundige Praktyk

Die volgende terme se omskrywings of vertalings moet gewysig word soos aangedui, omdat die toepaslike Standpunte oor Algemeen Aanvaarde Rekeningkundige Praktyk verander is:

Accounting assumptions Rekeningkundige aannames. Dit behoort as Rekeningkundige veronderstellings vertaal te word (verwys RE 000.22).

Accounting policies Rekeningkundige beleid. The specific principles, bases, conventions, rules and practices adopted by an enterprise in preparing and presenting financial statements. (AC 103.05)

Amortisation Amortiseer. Systematic allocation of the depreciable amount of an intangible asset over its useful life. (AC 129.09)

Annual report Jaarverslag. A report for shareholders and other interested parties prepared once a year. Includes a balance sheet, an income statement, a statement showing either all changes in equity or changes in equity other than those arising from capital transactions with owners and distributions to owners, cash flow statements, accounting policies and explanatory notes. (AC 101.08)

Associate Geassosieerde. An enterprise in which the investor has significant influence and which is neither a subsidiary nor a joint venture of the investor. (AC 110.02)

Cash flow statement Kontantvloeistaat. A statement that reflects the sources and uses of cash and cash equivalents for a period.

Contingent asset Voorwaardelike bate. A possible asset that arises from past events and whose existence will be confirmed only by the occurrence or nonoccurrence of one or more uncertain future events not wholly within the control of the enterprise. (AC 130.11)

Contingent liability Voorwaardelike aanspreeklikheid. A possible obligation that arises from past events and whose existence will be confirmed only by the occurrence or nonoccurrence of one or more uncertain future events not wholly within the control of the enterprise, or a present obligation that arises from past events but is not recognised because it is not probable that an outflow of resources embodying economic benefits will be required to settle the obligation, or the amount of the obligation cannot be measured with sufficient reliability. (AC 130.11)

Cost Koste. The amount of cash or cash equivalents paid or the fair value of the other consideration given to acquire an asset at the time of its acquisition or production. (AC 129.08)

Current asset Bedryfsbate. An asset that is expected to be realised in, or is held for sale or consumption in the normal course of the enterprise's operating cycle, or is held primarily for trading purposes or 
for the short term, and expected to be realised within twelve months of the balance sheet date, or is cash or a cash equivalent asset that is not restricted in its use. (AC 101.58)

Current liability Bedryfslas. A liability that is expected to be settled in the normal course of the enterprise's operating cycle, or is due to be settled within twelve months of the balance sheet date. (AC 101.61)

Current tax Lopende belasting. The amount of income tax payable (recoverable) in respect of the taxable profit (tax loss) for a period (AC 102.09)

Debtor Debiteur. Person who has an obligation to pay another (creditor). Also referred to as Account receivable or receivables. (AC 101 Appendix)

Deferred tax Uitgestelde belasting. The amount of taxation expense, the amount of which has been postponed or prepaid as a result of temporary differences. If the deferred tax has a cumulative credit balance, income tax will be payable in future periods. Where a cumulative debit balance exists income tax will be recoverable in future. (AC 102)

Depreciable amount Afskryfbare bedrag. The cost of an asset, or other amount substituted for cost in the financial statements, less its residual amount which is to be depreciated over its useful life. (AC 123.10)

Depreciation Depresiasie; waardevermindering. The systematic allocation of the depreciable amount of an asset over its useful life. (AC 123.10)

Earnings per share Verdienste per aandeel. Die omskrywing van $P$ moet soos volg gewysig word:

$\mathrm{P}=$ Profit, including equity profit from associate and extraordinary item, before tax.

Equity Ekwiteit. Die omskywing wat gegee word, verskil van die omskrywing verskaf in RE 000, daarom moet die verwysing na AC 000 verkieslik uitgelaat word, of die omskrywing moet aangevul word met die volgende:

"the residual interest in the assets of the enterprise after deducting all its liabilties". (AC 000.49)

Equity basis/method of accounting Ekwiteitsbasis/-metode van verantwoording. Investment is initially recorded at cost and adjusted thereafter for the postacquisition change in the investor's share of net assets of the investee. The income statement reflects the investor's share of the results of operations of the investee. (AC 110.02)

Financial statements Finansiële state. Die gekursiveerde gedeelte moet bygevoeg word: "Financial statements of a company comprise a balance sheet, an income statement, a statement showing changes in equity, a cash flow statement, ..." 
Income statement Inkomstestaat. Hierdie staat bevat nie meer aanwendings van netto wins indien die vereistes van RE 101 nagevolg word nie. Die beskrywing is egter steeds korrek indien toegepas op eenmansake en vennootskappe.

Intangible asset Ontasbare bate. An identifiable nonmonetary asset without physical substance held for use in the production or supply of goods or services, for rental to others, or for administrative purposes. (AC 129.08)

Joint ventures Gesamentlike ondernemings. A contractual arrangement whereby two or more parties undertake an economic activity that is subject to joint control. (AC 119.02)

Lease Huur. An agreement whereby the lessor conveys to the lessee in return for a payment or series of payments the right to use an asset for an agreed period of time. (ED 128.04)

Minority interest Minderheidsbelang. That part of the net results of operations and of net assets of a subsidiary attributable to interests that are not owned, directly or indirectly through subsidiaries, by the parent. (AC 131.09)

Monetary item Monetêre item. Money held, and assets and liabilities to be received or paid, in fixed or determinable amounts of money. (AC 112.08)

Net realisable value Netto realiseerbare waarde. The estimated selling price in the ordinary course of business less the estimated costs of completion and the estimated costs necessary to make the sale. (AC 108.04)

Offset Verrekening. To deduct one amount from another where a Statement of Generally Accepted Accounting Practice requires it or where gains, losses and related expenses arising from the same or similar transactions and events are not material. (AC 101.35)

Overhead costs Bo-koste. Die term Drakoste word vereis deur RE 108.

Parent Moedermaatskappy. An enterprise that has one or more subsidiaries. (AC 131.09)

Provision Voorsiening. A liability of uncertain timing or amount. (AC 130.11)

Reducing balance method Verminderdesaldo-metode. A method of calculating depreciation by applying the rate to the carrying amount (nie "book value" nie).

Residual value Reswaarde. The net amount that the enterprise expects to obtain for an asset at the end of its useful life after deducting the expected costs of disposal. (AC 123.10)

Revenue Inkomste. The gross inflow of economic benefits during the period arising in the course of the ordinary activities of an enterprise when those inflows result in increases in equity, other than 
increases relating to contributions from equity participants. (AC 111.09)

Taxable profit/loss Belasbare wins/verlies. The profit/loss for a period, determined in accordance with the rules established by the taxation authorities, upon which income taxes are payable (recoverable). (AC 102.09)

Revenue Inkomste. The gross inflows of economic benefits during the period arising in the course of the ordinary activities of an enterprise when those inflows result in increases in equity, other than increases relating to contributions from equity participants. (AC 111. 09).

\section{Nuwe terminologie vereis deur Standpunte van Algemeen Aanvaarde Rekeningkundige Praktyk}

Die volgende terme wat algemeen gebruik word of deur nuwe Standpunte oor Algemeen Aanvaarde Rekeningkundige Praktyk gebruik word, is uitgelaat en oorweging behoort geskenk te word aan hul insluiting in die werk:

Absorption Absorpsie.

Accounting profit Rekeningkundige wins. The net profit or loss for a period before deducting tax expenses. (AC 102.09)

Borrowing costs Leenkoste. Interest and other costs incurred by an enterprise in connection with the borrowing of funds. (AC 114.04)

Carrying amount Drabedrag. The amount at which an asset is recognised in the balance sheet after deducting any accumulated depreciation (amortisation) and accumulated impairment losses thereon. (AC 128.06)

Cash Kontant. Comprises cash on hand and demand deposits. (AC 118.07)

Cash equivalents Kontantekwivalente. Short-term, highly liquid investments that are readily convertible to known amounts of cash and are subject to insignificant risk of changes in value. (AC 118.07)

Charge Debiteer.

Control Beheer. The power to govern the financial and operating policies of an economic activity so as to obtain benefits from it. (AC 119.02)

Defined benefit plan Omskrewevoordeel-plan. Retirement benefit plan under which amounts to be paid as retirement benefits are determined by reference to a formula, usually based on employees' remuneration and/or years of services. (AC 116.06)

Defined contribution plan Omskrewebydrae-plan. Retirement plans under which amounts to be paid as retirement benefits are determined by reference to contributions to a fund, together with the investment earnings thereon. (AC 116.06) 
Equity instrument Ekwiteitsinstrument. Any contract that evidences a residual interest in the assets of an enterprise after deducting all of its liabilities. (AC 125.07)

Financial instrument Finansiële instrument. Any contract that gives rise to both a financial asset of one enterprise and a financial liability or equity instrument of another enterprise. (AC 125.07)

Financial asset Finansiële bate. Any asset that is cash, a contractual right to receive cash or another financial instrument, a contractual right to exchange financial instruments with another enterprise under conditions that are potentially favourable, or any equity instrument of another enterprise. (AC 125.07)

Financial liability Finansiële las. Any liability that is a contractual obligation to deliver cash or another financial asset to another enterprise, or to exchange financial instruments with another enterprise under conditions that are potentially unfavourable. (AC 125.07)

Financing acitvities Finansieringsaktiwiteit. Activities that result in changes in the size and composition of the equity capital and borrowings of the enterprise. (AC 118.07)

Forward cover Termyndekking.

Fundamental error Fundamentele fout. Errors discovered in the current period that are of such significance that the financial statements of one or more prior periods can no longer be considered to have been reliable at the date of their issue. (AC 103.05)

Impairment loss Waardedalingsverlies. The amount by which the carrying amount of an asset exceeds its recoverable amount. (AC 128.06)

Interim period Tussentydperk. A financial reporting period shorter than a full financial year. (AC 127.05)

Investing activities Beleggingsaktiwiteite. The acquisition and disposal of long-term assets and other investments not included in cash equivalents. (AC 118.07)

Joint control Medebeheer. The contractually agreed sharing of control over an economic activity. (AC 119.02)

Onerous contract Beswarende kontrak. A contract in which the unavoidable costs of meeting the obligation under the contract exceeds the economic benefits expected to be received under it. (AC 130.11)

Ordinary activities Gewone bedrywighede. Any activities that are undertaken by an enterprise as part of its business and such related activities in which the enterprise engages in furtherance of, incedental to, or arising from these activities. (AC 103.05)

Ordinary shares Gewone aandele. An equity instrument that is subordinate to all other classes of equity instruments. (AC 104.07)

Payables Die term word in AC 101 gebruik. Daar bestaan nie 'n algemeen aanvaarde Afrikaanse term daarvoor nie. 
Potential ordinary shares Potensiële gewone aandele. A financial instrument or other contract that may entitle its holder to ordinary shares. (AC 104.07)

Proportionate consolidation Eweredige konsolidasie. A method of accounting and reporting whereby a venturer's share of each of the assets, liabilities, income and expenses of a jointly controlled entity is combined on a line-by-line basis with similar items in the venturer's financial statements, or reported as separate line items in the venturer's consolidated financial statements. (AC 119.02)

Receivables Die term word in AC 101 gebruik. Daar bestaan nie ' $n$ algemeen aanvaarde Afrikaanse term daarvoor nie.

Record Verantwoord.

Recoverable amount Verhaalbare bedrag. The higher of an asset's set selling price and its value in use. (AC 128.06)

Redemption premium Aflossingspremie.

Related parties Verwante partye. Parties are considered to be related if one party has the ability to control the other party or exercise significant influence over the other party in making financial and operating decisions. (AC 126.05)

Reorganisation Reorganisasie.

Reporting period Verslagdoeningstydperk.

Restructuring Herstrukturering. A programme that is planned and controlled by management, and materially changes either the scope of a business undertaken by an enterprise, or the manner in which that business is conducted. (AC 130.11)

Retirement benefit plans Aftreevoordeelplanne. Arrangements whereby an enterprise provides benefits for its employees on or after termination of service (either in the form of an annual income or as a lump sum) when such benefits, or the empoyer's contributions towards them, can be determined or estimated in advance of retirement from the provisions of a document or from the enterprise's practices. (AC 116.06)

Significant control Beduidende invloed. The power to participate in the financial and operating decisions of an economic activity, but without control or joint control over those policies. (AC 119.02)

Temporary differences Tydelike verskille. Differences between the carrying amount of an asset or liability in the balance sheet and its tax base. (AC 102.09)

Tax base Belastingbasis. The amount attributable to an asset or liability for tax purposes. (AC 102.09)

Trade mark Handelsmerk. The book value of a trade mark is regarded as a noncurrent asset.

Useful life Nutsduur. Either the period of time over which an asset is expected to be used by an enterprise, or the number of production 
or similar units expected to be obtained from the asset by an enterprise. (AC 128.06)

Value in use Gebruikswaarde. The present value of estimated future cash flows expected to arise from the continuing use of an asset and from its disposal at the end of its useful life. (AC 128.06)

Warrants/options Bewyse/opsies. Financial instruments that give the holder the right to purchase ordinary shares. (AC 104.07)

\section{Gevolgtrekking}

Die woordeboek is 'n baie bruikbare hulpmiddel vir alle gebruikers van finansiële state, maar veral vir studente wat die eerste keer met rekeningkundige terme te doen kry. Die outeurs van enige tegniese navorsings- of handboek oor rekeningkunde is egter uitgelewer aan die snelle verandering as gevolg van die internasionaliseringsproses wat tans steeds aan die gang is. Die proses het egter alreeds ver gevorder en enige veranderinge wat aan die woordeboek aangebring word, behoort 'n redelike lewensduur te hê.

\section{Bronnelys}

(Al die dokumente is deur die Suid-Afrikaanse Instituut van Geoktrooieerde Rekenmeesters, Kengray, Suid-Afrika gepubliseer.)

\section{Afrikaanse dokumente}

$\begin{array}{lll}\text { Jaar } & \text { Verwysingsnr. } & \text { Naam van dokument } \\ 1990 & \text { RE } 000 & \text { Raamwerk vir die opstel en aanbieding van finansiële state } \\ 1999 & \text { RE } 101 & \text { Aanbieding van finansiële state } \\ 1999 & \text { RE } 102 & \text { Inkomstebelasting } \\ 1995 & \text { RE } 108 & \text { Voorraad } \\ 1999 & \text { RE } 117 & \text { Eindigende bedrywighede } \\ 1999 & \text { RE } 123 & \text { Eiendom, aanleg en toerusting } \\ 1999 & \text { RE } 131 & \text { Besigheidsamevoegings }\end{array}$

\section{Engelse dokumente}

$\begin{array}{lll}\text { Jaar } & \text { Verwysingsnr. } & \text { Naam van dokument } \\ 1990 & \text { AC } 000 & \begin{array}{l}\text { Framework for the preparation and presentation of financial state- } \\ \text { ments } \\ \text { Presentation of financial statements }\end{array}\end{array}$




\begin{tabular}{|c|c|c|}
\hline 1999 & AC 102 & Income taxes \\
\hline 1995 & AC 103 & $\begin{array}{l}\text { Net profit or loss for the period, fundamental errors and changes in } \\
\text { accounting policies }\end{array}$ \\
\hline 1998 & AC 104 & Earnings per share \\
\hline 1995 & AC 108 & Inventories \\
\hline 1999 & AC 110 & Accounting for investments in associates \\
\hline 1994 & AC 111 & Revenue \\
\hline 1998 & AC 112 & Accounting for the effects of changes in foreign exchange rates \\
\hline 1995 & AC 114 & Borrowing costs \\
\hline 1996 & AC 116 & Retirement benefit costs \\
\hline 1999 & AC 117 & Discontinuing operations \\
\hline 1996 & AC 118 & Cash flow statements \\
\hline 1999 & AC 119 & Financial reporting of interests in joint ventures \\
\hline 1999 & AC 123 & Property, plant and equipment \\
\hline 1997 & AC 125 & Financial instruments: disclosure and presentation \\
\hline 1997 & AC 126 & Related party disclosure \\
\hline 1997 & AC 126 & Interim financial reporting \\
\hline 1999 & AC 128 & Impairment of assets \\
\hline 1999 & AC 129 & Intangible assets \\
\hline 1999 & AC 130 & Provisions, contingent liabilities and contingent assets \\
\hline 1999 & AC 131 & Business combinations \\
\hline 1999 & AC 132 & $\begin{array}{l}\text { Consolidated financial statements and accounting for investments in } \\
\text { subsidiaries }\end{array}$ \\
\hline 1998 & ED 128 & Leases \\
\hline
\end{tabular}

